\title{
THE EXPERIENCES OF ADOLESCENTS ORPHANED BY HIV/AIDS-RELATED CONDITIONS
}

\section{Louw, JMC Joubert}

\section{INTRODUCTION}

The work environment of social workers in South Africa is riddled with new and complex social problems, often draining the available resources (Giese, Meintjes, Croke \& Chamberlain, 2003:7). Personnel in rural areas are confronted with huge numbers of orphaned children in need of urgent statutory intervention, mostly because of the economic burden brought about by their "orphan" status. Very little time can be spent on the socio-emotional care of these children, as the emphasis largely falls on the provision of basic needs, such as grants, school uniforms and food.

Adolescents are often called upon to become functional heads of households, whilst still being children themselves. Some adolescents are nursing terminally ill parents or siblings. Others have to rely on already poverty-stricken extended family members for support and nurturing (Meintjes, Budlender, Giese \& Johnson, 2005:238). Normal developmental tasks for them are complicated by added stress brought about by their orphaned care status (Richter, Manegold \& Pather, 2004:13; UNICEF, 2003:3).

Adolescents in this situation have to cope with the deprivation of a childhood and the imperative to assume adult responsibilities as household provider (Nelson Mandela Children's Fund, 2001:27). The adolescents cared for in a substitute family are also affected by the illness and death of their parents.

Strode and Grant (2001:3-32) conducted research in 2001 to determine the level of stigmatisation and discrimination children experience in South Africa because of HIV/AIDS. They concluded their study with the most common emotional experiences of children affected and infected:

- Seriously diminished sense of self-worth;

- Attitude of powerlessness;

- Unresolved and unventilated grief;

- Worry about ill parents, the future and poverty.

The Department of Health (2007:3), in the Social Tract module on HIV-related stigma, explains that the process of stigmatisation creates blaming and shaming, and often results in isolation. People think that they no longer have the qualities that make them worthy of respect and dignity. People act on their beliefs and this often creates active discrimination and human rights abuses.

Adolescence can be defined as the developmental stage that commences with puberty and ends with adulthood, in which sexual maturation and social, psychological and physical changes occur (Feldman, 2004:412, Louw, Van Ede \& Louw, 1998:388). The term "orphan" refers to children who have become vulnerable because their parents or caregivers can no longer care for them because they are either very ill or have died because of HIV/AIDS (Department of Social Development, 2003:33; Richter et al., 2004:3).

This research focused on the exploration and description of the experiences of adolescents orphaned by HIV/AIDS-related conditions. The goal of this study was to improve the knowledge base and insight of social workers in order to enable them to render more effective services. 


\section{RESEARCH QUESTION}

The formulation of a research question was relevant as the study was qualitative and exploratory. The following question summarised the objectives of the study and determined the design of the study:

What are the experiences of adolescents orphaned by HIV/AIDS-related conditions in the Gert Sibande region of Mpumalanga?

\section{RESEARCH APPROACH AND METHODOLOGY}

\section{Phase one: Choosing the research problem}

The rationale for the choice of the topic was discussed in the introduction.

\section{Phase two: Deciding to use a qualitative research approach}

To answer the research question, a qualitative approach was chosen. Bless and Higson-Smith (2000:156) defined qualitative research as: "Research conducted using a range of methods which use qualifying words and descriptions to record and investigate aspects of social reality".

\section{Phase three: Selecting the qualitative research design}

Poggenpoel (1998:349) explains the concept of a research procedure as follows: “... by observing the problem and studying naturally occurring innovations and other prototypes, the researcher can identify procedural elements for use in the intervention".

Phenomenology was seen as the most appropriate strategy to conduct the research. Neuman (2000:23) regards a phenomenological study as one which describes the meaning that experiences of a phenomenon, topic or concept has for various individuals. The research was therefore conducted by using a phenomenological strategy.

Information was gathered using words and descriptions to give meaning to the social reality as experienced by adolescents orphaned by HIV/AIDS-related conditions. Tutty, Rotthery and Grinnell (1996:4) describe qualitative research as the study of people in their natural environment as they go about their daily lives. It tries to understand how people live, how they talk and behave, and what captivates or distresses them. It also strives to understand the meaning that people's words and behaviours have for them. Through this study the researcher wanted to explore the experiences of adolescents in order to understand the meaning they attach to these experiences.

\section{Phase four: Preparing for data collection}

The following were decided upon before the implementation of the data-collection phase.

\section{- Setting}

The data-collection site was the Gert Sibande (Eastvaal) District of Mpumalanga. According to the Mpumalanga Population Unit, 320000 to 352000 persons in Mpumalanga are infected with HIV or have AIDS. (Department of Social Services, Population and Development, 2000:10). This represents $11 \%$ of the population in the province. According to the Population Unit, there is a proven relationship between poverty and HIV/AIDS. With a poverty rate of $57 \%$ and the antenatal HIV prevalence close to $30 \%$ in the year 2000, it is clear that the Mpumalanga Province is extremely vulnerable to HIV/AIDS and its consequences. The Actuarial Society of South Africa calculated that 46231 children would be without their mothers in 2004 in this province (Department of Social Services, Population and Development, 2000:10). 
- Data-collection boundaries

The following criteria determined inclusion or exclusion of a person from the sample:

- Ability to understand English;

- Age: adolescents between 13 and 18 years;

- Care status (orphaned or not);

- Person and circumstances of the family known to or nursed by a registered Home-Based Care Group;

- Willingness to participate;

- Orphaned for a period exceeding six months;

- Confirmation of the AIDS-like symptoms of the parent before he/she passed away from a family member or health service provider;

- Registered as a client at the Department of Health and Social Services, Gert Sibande region.

\section{- Sampling technique}

Probability sampling was used in this study. A combination of purposive and stratified sampling was thus used to identify 15 adolescent participants in the study. Babbie (2004:183) describes purposive sampling as a sampling method entirely based on the judgement of the researcher. The sampling method was used to find elements that contained the most characteristic, representative or typical attributes of the population.

The researcher conducted the fieldwork by obtaining the names of possible participants from the social workers in the region. Contact was made with them with the assistance of the relevant caseworker or home-based care coordinator.

\section{Phase five: Data collection and data analysis}

Information was gathered by means of individual interviews aided by the use of a semi-structured interview schedule. The interview schedule was based on the Developmental Assessment Model (Viviers, 2004:1) regularly used by social workers. Interviews were conducted in English with five young people, one in Afrikaans and nine in isiZulu. Different interpreters were utilised to ensure the quality of translations. On completion of this, data analysis commenced. Interviews took place in Hendrina, Ermelo, Carolina, Chrissiesmeer and Piet Retief. Interviews were recorded and the data were then transcribed into English.

It is important to note the context in which the interviews took place. The young people who participated in the interviews all received some form of assistance from social workers, homebased care groups, children's home or the Secure Care Facility. This means that the basic needs of the participants were all met and that directly influenced the possible repetition of the study. The young persons were reflecting back on their experiences. No young person was interviewed before assistance was given, as this would have been unethical and demeaning.

According to Alpaslan and Mabutho (2005:282), data analysis should include examining, categorising, tabulating or otherwise recombining the evidence to address the research question.

\section{Phase six: Data verification}

Guba and Lincoln's (1989:52) method of evaluation of the trustworthiness of the information assisted the researcher by providing criteria and strategies that could be implemented in the 
research process. It became clear from the process and results that the findings can be transferred successfully to a similar population.

\section{DISCUSSION OF FINDINGS}

The following research findings forming part of this article resulted from 15 in-depth semistructured interviews conducted with adolescents between the ages of 13 and 18 .

\section{A biographical profile of the research participants}

Table 1 provides geographical information regarding the participants.

\section{TABLE 1}

BIOGRAPHICAL PROFILE OF RESEARCH PARTICIPANTS

\begin{tabular}{|c|c|c|c|c|c|c|c|}
\hline •⿳亠丷厂犬土 & 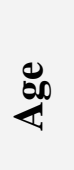 & Gender & $\begin{array}{l}\text { School } \\
\text { Grade }\end{array}$ & $\begin{array}{l}\text { Area of } \\
\text { origin }\end{array}$ & $\begin{array}{l}\text { Parental } \\
\text { Situation }\end{array}$ & Current caregiver & $\begin{array}{c}\text { In receipt of } \\
\text { foster care } \\
\text { grant }\end{array}$ \\
\hline $\mathrm{NH}$ & 17 & Male & 11 & Urban & Both deceased & Child-headed household & No \\
\hline GU & 15 & Female & 9 & Urban & Both deceased & Maternal uncle & Yes \\
\hline TB & 15 & Female & 9 & $\begin{array}{l}\text { Semi- } \\
\text { urban }\end{array}$ & Both deceased & With maternal aunt & No \\
\hline MZ & 17 & Male & $\begin{array}{l}\text { Not in } \\
\text { school }\end{array}$ & Rural & $\begin{array}{l}\text { Mother unknown; } \\
\text { Father deceased }\end{array}$ & $\begin{array}{c}\text { Stepmother } \\
\text { (In Secure Care at time } \\
\text { of interview) }\end{array}$ & No \\
\hline $\mathrm{TH}$ & 15 & Female & 9 & $\begin{array}{l}\text { Semi- } \\
\text { urban }\end{array}$ & Both deceased & Maternal Grandmother & Yes \\
\hline $\mathrm{ZA}$ & 18 & Female & 12 & Urban & Both deceased & Maternal aunt & Yes \\
\hline NOMK & 13 & Female & 8 & Urban & Both deceased & Maternal aunt & Yes \\
\hline $\mathrm{BD}$ & 17 & Male & $\begin{array}{l}\text { Not in } \\
\text { school }\end{array}$ & Semi urban & $\begin{array}{l}\text { Mother deceased; } \\
\text { father unknown* }\end{array}$ & $\begin{array}{l}\text { Child-headed household } \\
\text { (In Secure Care at the } \\
\text { time of the interview) }\end{array}$ & No \\
\hline AY & 14 & Female & 8 & $\begin{array}{l}\text { Semi- } \\
\text { urban }\end{array}$ & Both deceased & Maternal grandmother & Yes \\
\hline BAWN & 17 & Female & 11 & Urban & Both deceased & Child-headed household & No \\
\hline SF & 13 & Male & 3 & $\begin{array}{l}\text { Semi- } \\
\text { urban }\end{array}$ & $\begin{array}{l}\text { Mother deceased, } \\
\text { father unknown* }\end{array}$ & Children's Home & $\begin{array}{l}\text { Children's } \\
\text { Home }\end{array}$ \\
\hline NVA & 13 & Female & 1 & Rural & Both deceased & Place of safety parent & No \\
\hline BERN & 13 & Female & 4 & Urban & Both deceased & Children's Home & $\begin{array}{l}\text { Children's } \\
\text { Home }\end{array}$ \\
\hline SIMP & 14 & Female & 4 & Rural & Unknown* & Children's Home & $\begin{array}{l}\text { Children's } \\
\text { Home }\end{array}$ \\
\hline NJ & 14 & Male & 6 & Urban & Both deceased & Children's Home & $\begin{array}{l}\text { Children's } \\
\text { Home }\end{array}$ \\
\hline
\end{tabular}

* Parents' whereabouts unknown at the time of the interview.

Three of the 15 participants live in child- headed households, in which they are the functional heads of the household. Four participants live in a Children's Home, one with a Place of Safety Parent (waiting for the completion of a Children's Court Inquiry) and five are in foster care with 
relatives. Two young persons were interviewed whilst being cared for in a Secure Care Awaiting Trial facility.

\section{Thematic discussion}

\section{THEME 1: SOURCES OF SUPPORT, HURT AND ANGER}

This theme and its sub-themes dealt with the young persons' perception of the world around them, especially about family members, missing parents, the church and others they hoped would assist or care for them.

This theme was divided into the following sub-themes:

- Relatives as a source of hurt and anger;

- Relatives as source of support and care;

- Friends as a source of support and hurt;

- The community as a source of hurt and anger;

- The school as a source of support;

- God and the church as a source of support and hurt.

The central developmental task of the young adolescent is emancipation from parents, as well as the development of identity (Dwivedi, 1999:69). It appeared as if being dependent on other people, like family members, whilst they actually need to move towards guided independence is a source of frustration and pain for the participants. "Instant independence" in the case of childheaded households appeared to have left the participants with worry, fear and anger, as they are not ready to take on all adult responsibilities.

Anger and sadness were the two prevailing emotions noted by the researcher. Anger was directed at relatives and friends who could not live up to expectations, parents who abandoned them, community members who humiliated them and God who chose to "punish" them. Some of the young persons endured terrible trauma (like NVA who was raped for payment by uncles with the permission of the grandmother), whilst others experienced normal adolescent conflicts. According to their research, Meintjes, Moses, Berry and Mampane (2007:21) indicate that orphans generally experiences abuse or neglect.

Foster (1997:5) indicated that some uncles and aunts of orphaned children are reluctant to foster a relative's children, because it would result in their own children's standard of living suffering. If forced by economic or other circumstances to choose between their own and fostered children, they would show preference towards their own children.

It appears as if the recognition and assistance of the paternal family is of great importance to adolescents cared for by maternal families. Those cared for by paternal families are using that surname and they appeared to be very proud to be associated with the surname. Unfortunately, the opposite was true for most of the participants:

Child-headed households are often an extreme result of rejection or neglect by extended families. Foster (1997:5) described the factors that may predispose the development of a child-headed household, namely:

- Reluctance of relatives to foster orphans;

- Lack of contact of relatives with the children;

- Presence of adolescents able to care for younger children; 
- Death of a single mother leaving illegitimate children;

- Death of a grandparent-caregiver;

- Children preferring to live in child-headed households, because of inheritance of the residence by the surviving children or because of the wish of a dying parent.

The circumstances of the three child-headed households that formed part of the study all fitted these criteria. It became clear that very serious problems start when grandparents also pass away. Some of the participants were placed in a Children's Home after the death of their grandparents, as no possible foster parents were left.

\section{TABLE 2}

THEME 1: SOURCES OF SUPPORT, HURT AND ANGER

\begin{tabular}{|c|c|c|}
\hline SUB-THEME & CONTEXT & EXTRACT FROM INTERVIEW \\
\hline \multirow[t]{4}{*}{$\begin{array}{l}\text { Relatives as a } \\
\text { source of hurt } \\
\text { and anger }\end{array}$} & $\begin{array}{l}\text { Anger } \\
\text { directed at } \\
\text { family } \\
\text { members }\end{array}$ & $\begin{array}{l}\text { My father's family is not supporting me, I do not know why, because } \\
\text { they are not poor... it is not as if they are not friendly- they always } \\
\text { invite me to their home when they see me on the street. I do not } \\
\text { understand why they do not help me. - TH } \\
\text { My grandmother said to the court - she is tired of me. I am lying, it } \\
\text { (rapes) never happened. She wishes I could stand in the road and a } \\
\text { truck could drive over me. That is how she feels about me. She made } \\
\text { me do bad things and she told everyone I have the sickness (HIV) so } \\
\text { that they could give her money for medicine. - NVA }\end{array}$ \\
\hline & $\begin{array}{l}\text { Anger } \\
\text { directed at } \\
\text { paternal } \\
\text { families }\end{array}$ & $\begin{array}{l}\text { I hate my father's family! I hate them! Because when my father passed } \\
\text { away in 1993, my father was shot, they said my mother's boyfriend } \\
\text { killed my father. Even to my mother's funeral, they did not come. That } \\
\text { is why I hate them. - BAWN } \\
\text { He called for me when he was in his deathbed, but I told him it is no } \\
\text { use calling for me when I am in High School, while he was not there } \\
\text { when me and my mother needed him... they (father's family) know me, } \\
\text { but I don't really like them. When he was in his deathbed, he } \\
\text { remembered, 'Oh, I have a child' and when I got there he did not even } \\
\text { know me. - GU }\end{array}$ \\
\hline & $\begin{array}{l}\text { Humiliation } \\
\text { to beg for } \\
\text { food }\end{array}$ & $\begin{array}{l}\text { It was very hurtful. They (family) would give you food because of your } \\
\text { mother, but they would say nasty things before they give you that food. } \\
\text { Like I am a beggar, always hungry. -BD } \\
\text { I thought we will die of hunger too after my granny died. -BERN } \\
\text { When my grandmother died, I had to do everything. It was so bad. The } \\
\text { "small uncle" nearby buried her. Later they called the social workers } \\
\text { because they could see we are starving. - SIMP } \\
\text { People told me they will take care of us, but they wanted money from } \\
\text { the social workers. They promised me R50 if I told the social worker I } \\
\text { want to stay there. - SF }\end{array}$ \\
\hline & $\begin{array}{l}\text { Conflict } \\
\text { about chores }\end{array}$ & $\begin{array}{l}\text { I go to school until } 15 \mathrm{~h} 00 \text {. Then I come home at } 15 \mathrm{~h} 30 \text {. Then I have to } \\
\text { chop wood, fetch water and fetch the cattle. I work harder than the } \\
\text { other children, because I am the eldest boy. But when I don't get to } \\
\text { finish everything, my stepmother's child (a young adult of } 20 \text { ) say that } \\
\text { I don't deserve to eat because my work is not done. - MZ } \\
\text { My eldest cousin thinks she is my mother - she is always on my case. } \\
\text { She always thinks I am going to get drunk or pregnant if I try to go } \\
\text { somewhere...I really hate her. - AY }\end{array}$ \\
\hline
\end{tabular}

Conflict (justified or not), especially about chores and other children of the family where they are currently staying, often makes the participants feel that they don't belong to the family. Conflict appears to be inherent to adolescent relationships, especially when they begin to realise that 
adults are not always right (Light, 2004:3). Conflict usually pertains to chores, finances, appearance and substance abuse. In addition, family relationships, school curfews, dating, friends and sexual behaviour cause disagreement between parents (and also alternative caregivers) and their teenagers (Light, 2004:4). It appeared to researcher as if the participants experienced this sometimes normal conflict as rejection and extremely hurtful.

\section{Sub-theme 1.2: Relatives as a source of support}

Barnett and Blaikie (1992:119) are of the opinion that orphans are mostly cared for by grandparents or maternal aunts or uncles. Participants experienced them as supportive, especially in terms of nursing of the ill and funerals.

Older siblings and even a helper at home appeared to be perceived as trustworthy sources of emotional support and advice. Uncles and aunts are seen as "caring but too busy to listen". It became clear that emotions are not discussed openly in the family, especially not about the dead. In most instances photos of the deceased are not displayed openly, as the deceased can only be approached at the gravesite as an ancestor.

There is no-one to listen...everyone is doing their own thing. I can only talk to my sister or my friends, but sometimes they give bad advice! - NH

\section{Sub-theme 1.3: Friends as source of support and hurt}

The role played by peers in adolescence is critical (Castrogiovanni, 2004:1) as they are helping the adolescent to define his or her identity. It appears, however, that the strain of being an orphan may complicate these relationships. Mabutho (2004:58) quoted McKerrow (1994) about the difficulties orphaned adolescents may experience: "Their anger at the unfairness of the world often contaminates their peer group relationships as they are likely to feel bitter that their friends have not had to cope with what they have had to deal with".

I only have classmates, no friends. - GU

I have three good friends. We talk and do hair, maybe walk around a bit. But with problems I would rather talk to my sister. The other girls talk about the way I dress. I don't have enough clothes. They say bad things. - TH

I have many friends, but I only talk to one. Some of the others gossip about me, because I am in the children's home. They want to know why. - BERN

\section{Sub-theme 1.4: The community as a source of support and hurt}

A perception of "being different" can clearly seen in this sub-theme (Department of Health, 2007:3-5). Young persons participating in the study appeared to be suspicious of community members, except persons associated with the home-based care groups, who served as a regular source of support to some. Young participants experienced feelings of being different and being observed. This is the experience of adolescents under normal circumstances (imaginary audience), now complicated by stressful circumstances.

They used to treat me as if I have got some or other decease: I don't have parents and they have parents... I can just live my live alone. - GU

They say ...God punished you for being like this...for what you are. - GU

They (home-based care group) brought food when they found out. If it was not for them...I don't know. - BAWN.

"Aids gave renewed life to the concept of disease as punishment and other moral judgments" (Department of Health, 2007:3). 


\section{Sub-theme 1.5: The school as a source of support and hurt}

All of the participants reported their school and a teacher or teachers as a source of support, even though BD was expelled from his school at some point because of rowdy behaviour. None reported discrimination because of unpaid school fees or poor school uniforms. MZ reported that his school demanded school fees for admission, but he was able to pay it. This was contrary to the expectation of the researcher, who expected some discrimination or abuse at school. Most participants reported pride in their ability to continue with school, despite their circumstances.

When my father was sick I could not go - me and my sister took turns to look after him. I passed last year...it was really a bad year, but I made it. - TB

\section{Sub-theme 1.6: God and the church as a source of support and hurt}

The young people had ambivalent reactions towards God and the church. It appears as if the support of the church often stops after the death and funeral of the parent, leaving the orphaned children to deal with their pain alone.

Why? Why does it happen to me? Why does it have to be me? So...sometimes I don't believe in God, because I feel He let me down. Maybe it would have been better if I had at least one parent...maybe I would then have believed that there is a God who cares for me. (The church helped) just with the funeral, they also left- just like a dream. - NH

\section{THEME 2: MY LIFE CHANGED AFTER I BECAME AN ORPHAN}

\section{Sub-theme 2.1: This is how my life changed}

SF's comment that "my happiness died with my mother" summarised the sadness and loneliness experienced by the participants.

The lack of permanency planning by the extended family as well as social workers was a source of worry for the young persons, as no contingency plans were made for them in case their current placement could continue. Uncertainty has serious implications for the emotional basis of the orphaned child (Geballe \& Gruendel, 1998:51; Meintjes et al., 2007:1-2).

Existing research suggests that the impact of HIV/AIDS at the household level may lead to sequential trauma associated with continuous traumatic stress. Many children suffer multiple losses - a father, a mother, siblings, grandparents, uncles, aunts and other relatives. In additions, they may lose friends, familiar surroundings, schooling and their hope for the future and their remaining childhood, and are subject to surges of loneliness and sadness, triggered by some memory (German, 2004:2,19).

I definitely don't have happiness in my life. I am happy... or I am pretending to be happy. I don't feel special. I have a girlfriend but she does not make me feel that special like my mother did. I cannot show the young ones that I am hurting because they will break apart. $-\mathrm{NH}$

Life is tough now. Because she was the one looking after us with clothing and all that. Sometimes I am hungry and have nothing to eat. Then I am tempted to go and steal. - BD

\section{Sub-theme 2.2: I feel... if I think of my parents}

The emotional demand of HIV/AIDS on children's lives is heartbreaking. The literature shows that parental death reduces children's self-esteem and increases depression, anxiety, conduct disturbance, academic difficulty, somatic complaints and suicidal acts in the long term (GrieselRoux, 2004:38). The researcher experienced that the participants found it difficult to 
communicate their emotions in depth verbally. Discomfort is often described as "feeling bad" or "it does not feel good". In a peer group discussion with two senior Zulu-speaking social workers (Mrs Mahlangu \& Mrs Mabena on 2005.10.14) it was explained that there are very few words in Zulu to describe emotions and that the discussion of emotions is not deemed appropriate by traditional households. Discussions about the deceased are also not seen as appropriate.

The young participants expressed the following emotions during the interviews:

TABLE 3

EMOTIONS EXPRESSED BY PARTICIPANTS

\begin{tabular}{|c|c|c|}
\hline EMOTION & CONTEXT & EXPRESSION \\
\hline Sadness & Remembering the parent & $\begin{array}{l}\text { "... We miss her a lot. I feel sadness if I think of her." } \\
\text { - "ZA } \\
\text { "I cry if I am reminded of her." - BERN }\end{array}$ \\
\hline Guilt & $\begin{array}{l}\text { Not being at father's funeral } \\
\text { Selling mother's } \\
\text { possessions to survive } \\
\text { Not being able to 'unveil } \\
\text { the tombstone' } \\
\text { Feeling guilty about being a } \\
\text { burden }\end{array}$ & $\begin{array}{l}\text { "I felt very bad, because I was not able to see him for the } \\
\text { last time." - MZ } \\
\text { "It felt so bad- she worked so hard for it, but we had no } \\
\text { choice." - ZA } \\
\text { "There is no tombstone. It feels so bad."- ZA } \\
\text { "I am just trouble. My grandmother said that. Where to get } \\
\text { food from?" - NOMV }\end{array}$ \\
\hline Loneliness & $\begin{array}{l}\text { At night } \\
\text { Talking about her family } \\
\text { Talking about feelings }\end{array}$ & $\begin{array}{l}\text { "I felt so lonely that I sometimes my mother is calling } \\
\text { me." - NH } \\
\text { "... so, I really have no-one left." - GU } \\
\text { "There is no-one to listen." - BAWN }\end{array}$ \\
\hline Humiliation & $\begin{array}{l}\text { Asking for food or money } \\
\text { About not having clothes }\end{array}$ & $\begin{array}{l}\text { "They talk and talk before they give. It makes me feel not } \\
\text { good inside." - BAWN } \\
\text { "It was very hurtful" - BD }\end{array}$ \\
\hline Anger & Why did it happen to me? & $\begin{array}{l}\text { "I am angry" - NH } \\
\text { "I was so angry. I ran away if someone wanted to help } \\
\text { me." - SF }\end{array}$ \\
\hline $\begin{array}{l}\text { Powerlessne } \\
\text { sS }\end{array}$ & Unable to cope & $\begin{array}{l}\text { "I did not know what to do anymore." - SIMP } \\
\text { "They did not want to help me." - MZ } \\
\text { "I am waiting for months now (for foster care grant)." - } \\
\text { BAWN }\end{array}$ \\
\hline Pain & Thinking about parent & $\begin{array}{l}\text { "I feel so much pain. I don't want to cry, because the last } \\
\text { time I cried was at my mother's funeral." - NH }\end{array}$ \\
\hline Irritation & $\begin{array}{l}\text { Not having a variety of food } \\
\text { Dealing with younger } \\
\text { cousins or siblings }\end{array}$ & $\begin{array}{l}\text { "Pap and eggs- it really irritates me." - NH } \\
\text { "They are noisy." - ZA } \\
\text { "I can only do homework when they went to bed." - NH }\end{array}$ \\
\hline $\begin{array}{l}\text { Fear and } \\
\text { Worry }\end{array}$ & $\begin{array}{l}\text { Looking after parents whilst } \\
\text { ill } \\
\text { Worry about what will } \\
\text { happen if grandparents die }\end{array}$ & $\begin{array}{l}\text { "I was so scared." - TH } \\
\text { "I was very worried, because he was the only person who } \\
\text { was looking after me." - MZ } \\
\text { "I worried when she (grandmother) also passed away". } \\
\text { - GU } \\
\text { "Things became really bad when my grandfather died. It } \\
\text { was so terrible when my grandmother also died and we } \\
\text { worried because we did not have anybody then." - SIMP }\end{array}$ \\
\hline
\end{tabular}

\section{Sub-theme 2.3: Poverty as a result of being orphaned}

Demmer (2004:40) indicated that the South African Social Welfare system is unable to adequately meet the needs of children orphaned by HIV/AIDS, as there are still thousands of children who are waiting for services. The provision of care for orphans when their foster parent 
grandparents pass away is also a worrying factor, as it appears from the study that children then depend on children's homes or child-headed families for care.

Food security is affected first when the breadwinner of the family gets sick or die. Foster (1997:15) mentioned food stinting and the selling of furniture and assets as a way in which a severely affected family attempts to cope with food shortages:

We only ate once a day for a long time- we only ate at night... maybe for two months. My granny tries to buy clothes. - BAWN

We did not have enough food at that time, because my father was not working. Sometimes we did not eat for two days. - TH

We did not have money or someone to fix the house. The roof was taken by the wind (blown away). So then we stayed outside most of the time. We only had pap to eat and sometimes maroggo. The uncles sometimes brought a chicken. - NVA

We had no food. Everything we had to ask. Sometimes we only drank water. The worst was when the small ones ask for food and I have nothing to cook. - SIMP

We had to sell the furniture of my mother. - ZA

Access to proper clothes and school clothes appears to be a constant source of worry and humiliation for the participants.

\section{Sub-theme 2.4: Coping with being an orphan}

Poverty resulting from the HIV/AIDS pandemic can lead to the sale of assets or land. Orphans may even have to turn to crime or sex as a survival option (Smart, Pleaner \& Dennil, 2000:93; USAID, 2002:4). Meintjes, Moses, Berry and Mampane (2007:22) explain: "Poverty exacerbates the difficulties for caregivers raising children, and heightens children's risk of neglect, abandonment and possibly abuse." The participants in the study reported the following strategies to cope with the sudden loss of parental income:

We were selling sweets and fruit. - BD

We don't have furniture anymore. It was sold for food. - BD

We had to ask food from the neighbours. - BD

I stole money...even from my grandmother to get food. I was also tempted to do housebreaking when we did not have anything to eat. That is why I am here (Secure Care Centre). - BD

\section{Sub-theme 2.5: How it was decided where i should stay}

Living with uncertainty poses a great challenge to the secure psychological base essential to a child's development of a healthy and functional personality (Geballe \& Gruendel, 1998:51). It was interesting to note that all the young persons who participated in the study initially remained in their original homes after their parents' death. They were only removed or assisted by family when serious problems arose. In some cases the young persons remained in the home they knew, mostly with grandparents or maternal family (for example AY, TH, GU). Richter et al. (2004:16) hold that older caregivers may have difficulties responding to the economic, health and psychological needs of children and that they may suffer severe resource constraints.

The absence of a formal family decision about their future is a constant source of disappointment and humiliation for the adolescents in child-headed households:

They (family) did not decide because we stayed in our homes. After the funeral, just immediately when we came back from the graveyard...two hours and we were left all alone. That is when we made the decision to sty away from them, because they showed us 
that they did not really care. $-\mathrm{NH}$

They knew my sister became sick and we had to look for food in the dustbins. They just made as if they did not know us. Except my grandfather, but he is old. Other people wanted us, but just for the money. When they saw they will not get it, they chased us away. - SF I always lived with my granny. It is my home. - AY

\section{THEME 3: PARENT'S ILLNESS AND DEATH}

Children's psychosocial distress begins with a parent's illness, and they are left emotionally and physically vulnerable by the death of one or both parents. They may suffer lingering emotional problems from attending to dying parents and seeing parents die (Hunter \& Williamson, 2002:17).

\section{Sub-theme 3.1: This is what I saw}

The clinical course of HIV/AIDS is disturbing to the infected person and affected family. The participants in the study were not required to reveal the actual illness of their deceased parent or parents, but to describe the symptoms they observed.

The last week before she passed away, she was unable to eat...she could only drink mageu... she could not swallow anything. It was so terrible. $-\mathrm{NH}$

He was coughing and sometimes he could not even walk. I had to make fire for him to keep him warm. He died at home, but I was not there. - MZ

It was terrible. Her face was so swollen, you could actually not see where her eyes were, cause the black thing of her eyes totally disappeared. It was so terrible - she had so much pain and she could not do anything. She was in a Pretoria hospital but they could no longer help her. - GU

She was coughing and blood and phlegm came from her mouth. She was screaming sometimes with pain. It was terrible. She died in hospital. - BD

She was so sick. She was talking no sense and she was urinating in bed. My sister ran away, she could not take it. I did not know what to do. They took her to hospital. - SF

\section{Sub-theme 3.2: Funerals and illness of other people}

According to German (2004:19), children affected by HIV/AIDS suffer multiple losses. This may result in "bereavement overload" (Richter et al., 2004:32-33; Geballe \& Gruendal, 1998:52). SIMP saw the death of both her primary caregivers in a period of six months. From the study it became clear that funerals and the illness of other persons are a source of secondary trauma for them, as it brings repressed memories and emotions to the fore.

I cannot handle funerals. I cannot handle it anymore, it is too painful. I don't want to remember. I don't want to cry. Even now, if you can tell me someone is sick, I would not ... even...the person could rather go. I am scared if people are really sick. - NH

It just came back when my grandmother also died. It brings back memories. You don't really cry for the person who died, but for your mother or grandmother. I prefer not to go to other people's funerals. I don't like dead people- I saw my grandmother also - now I rather stay in the car. - GU

\section{FINDINGS ON THE EXPERIENCES OF ADOLESCENTS ORPHANED BY HIV/AIDS- RELATED CONDITIONS}

The researcher is of the opinion that orphaned adolescents experience their environment both as supportive and hostile. Social workers featured seldom as a source of support, but rather as 
inconsistent providers of material needs and broken promises. Friends and siblings are the most trusted sources of support, together with home-based care groups. Hurt and anger are mostly the result of being betrayed, gossiped about or rejected by family members or those in helping professions.

All the participants reported some form of significant change in their life as a result of the death of a parent. Some experienced extreme poverty as a result of the loss of income. Deprivation and shame because of food shortages were some of the experiences related by the participants. Most of the young people reported feeling sad or depressed most of the time, struggling to understand what has happened to them.

The experiences of adolescent participants can be summarised as follows:

- They experience a lack of emotional and physical support from their extended families;

- Paternal families of unmarried parents are often not involved in the care of orphans;

- Poverty is often a result of being orphaned by HIV/AIDS-related circumstances, and leads to food stinting, inadequate clothing and shelter as well as acts of desperation like theft;

- The community and church are not perceived as supportive by adolescent orphans;

- Schools are seen as a source of support by most orphaned adolescents;

- Sadness and fear are the two most common emotions experienced by the orphaned adolescent;

- Home-based care groups are seen as the most constant source of assistance;

- The adolescent in a child-headed household has no legal protection against family members who want some of the deceased parents' possessions;

- Orphaned adolescents have insufficient opportunity to mourn their parents because of cultural norms;

- Traumatic memories are suppressed;

- Orphaned adolescents living with grandparents have a significant risk of being displaced for a second time, if grandparents become ill or pass away;

- Caregivers are not always capable or suitable to care for orphans;

- Awareness and prevention campaigns do not take cultural beliefs and practices into consideration.

\section{RECOMMENDATIONS}

Based on these findings, the following proposals are put forward for government and other social work service providers to consider.

\section{Recommendations for the improvement of services on a micro-level}

- Improved foster parent screening

The researcher is of the opinion that some family members are not suitable as foster parents and that it is not always in the interest of children to be placed with an extended family member.

- Improved awareness and prevention campaigns

Assistance of traditional leaders should be considered when prevention campaigns are planned. The distribution of condoms alone cannot create understanding and behaviour changes. 
- Establishment of support groups

Adolescents experience their siblings and friends as most reliable sources of support, and so support groups can therefore assist them to feel less isolated. Group assistance will enhance resilience.

- Life skills camps and programmes

Young persons in child-headed households need training in some of the basic life skills, such as cooking, personal hygiene and household chores, to meet their own needs. Camps held during the school holidays can also address issues such as self-awareness, emotional development and grief.

- After-school centres as respite care

Most of the participants indicated that they have very little assistance when it comes to homework and studying. They have to look after younger siblings, cook for them and wait until they go to bed before they can study themselves. The provision of after-school centres, where younger children can eat, play and be assisted with homework, will provide more free time to the adolescent who has care-giving responsibilities.

- Gender issues

Female respondents experienced that their education is considered to be of less importance than that of their brothers. In most cases it was the young girls who have to take care of the sick and dying parent(s) and to look after the younger children in the family.

\section{Recommendations for improvement of services on a macro-level}

- Strengthening of home-based care organisations

Home-based care organisations are perceived in a positive light by adolescent orphans and therefore these organisations can be strengthened by government and civil society to become fully-fledged social welfare organisations that can provide the following services:

- Support groups;

- Bereavement counselling;

- Consistent food security and economic support;

- Nursing of ill family members;

- After-school care;

- Provision of fun activities;

- Education of foster parents;

- Foster care supervision;

- Marketable skills training.

- Increased children's home capacity as last resort caregiver

Several orphaned adolescents will eventually need institutional care, even though care within the community would be the preferred option. An increase in this capacity is needed in order to provide for the escalating number of children orphaned by HIV/AIDS. This can prevent some children from living in child-headed households of falling prey to unscrupulous community members who take in children in order to obtain the foster care grant.

- Assisted living for child-headed households

Child-headed households appear to be a phenomenon that is here to stay. Some models of assisted living, such as the Isibindi Model, do exist but on a small scale. It is recommended that government should make provision for specific funding for this kind of project, including the employment of community childcare workers or auxiliary social workers. 
- Support from communities

Awareness within societies must be raised to create an environment that enables support for children affected by HIV/AIDS.

\section{Recommendations for improvement of services on a meso-level}

- Legislative changes

It is recommended that legislation be improved to protect the property of children orphaned by HIV/AIDS, as the appointment of a guardian from the family often leads to the assets of the children being distributed amongst family members. Changes to the Social Assistance Act to enable orphaned children to access financial assistance without a statutory process (socalled subsidised adoption) would also increase the quality of life of thousands of South African children.

- Provision of affordable anti-retroviral medication

The improvement of the life expectancy and quality of life of HIV-positive parents is the most logical manner in which to assist their children. It is recommended that suitable, affordable medication be made available as far as possible in order to increase life expectancy.

- National Youth Service

The National Youth Service may be a possible manner in which the unemployed late adolescent can be utilised in some community development, whilst earning a stipend. This will increase their own standard of living, as unemployment was identified as a source of serious stress for the late adolescents. This will also increase the employability of these young adults, as they will be exposed to the working world.

- Address gender issues

Give attention to the role of boys and girls to address gender discrimination.

- Reduce stigma and discrimination

Provide information to reduce stigmatisation and discrimination.

- Accelerate learning opportunities

Prevent adolescents dropping out of school by setting up community-based schools and/or informal education. Interactive radio instruction programmes for out-of-school children (IRI) must be explored.

- Provision of early childhood care and education

Provision of safe care for smaller children could give adolescents the opportunity to continue their own education or home care while parents are ill.

- Assisting schools to provide psychosocial support for affected children

School social workers could address the psycho-social problems of adolescent orphans.

- Work to prevent HIV infection among adolescents

Community mobilisation and awareness programmes must be made available and implemented.

\section{REFERENCES}

ALPASLAN, N. \& MABUTHO, S.L. 2005. The experiences of elderly grandmother caregivers and AIDS orphans. Social Work/Maatskaplike Werk, 41(3):276-295.

BABBIE, E. 2004. The basics of social research $\left(3^{\text {rd }}\right.$ ed). Belmont: Wadsworth/Thompson. 
BARNETT, T. \& BLAIKIE, P. 1992. Aids in Africa: Its presence and future impact. London: Belhaven Press.

BLESS, C. \& HIGSON-SMITH, C. 2000. Fundamentals of social research methods: An African perspective $\left(2^{\text {nd }}\right.$ ed $)$. Cape Town: Juta.

CASTROGIOVANNI, D. 2004. Adolescence: Change and continuity - peer groups. Available: http://inside.bard.edu/academic/specialproj/darling/adpeer1.htm. [Rev. 2004.08.06].

DEMMER, C. 2004. Loss and grief following the death of a patient with AIDS. Social Work/Maatskaplike Werk, 40(3):294-315.

DEPARTMENT OF SOCIAL SERVICES, POPULATION AND DEVELOPMENT. 2000. The demographics of poverty in Mpumalanga. Pretoria: Department of Social Services, Population and Development.

DEPARTMENT OF SOCIAL DEVELOPMENT. 2003. National guidelines for social services to children infected and affected by HIV/AIDS. Pretoria: National Department of Social Development.

DEPARTMENT OF HEALTH. 2007. Training manual- operational plan for comprehensive HIV and AIDS care, management and treatment for South Africa. Social Tract Module on HIV-related stigma. Available: http://www.doh.gov.za/docs/misc/hiv-f.html. [Rev. 2007.08.04].

DWIVEDI, K.N. 1999. Group work with children and adolescents. London: Jessica Kingsley Publishers.

FELDMAN, R.S. 2004. Child development ( $3^{\text {rd }}$ ed). USA: Pearson/Prentice Hall.

FOSTER, G. 1997. Children rearing children: A study of child-headed households. Paper presented at the Conference on the socio-demographic impact of AIDS in Africa, held 3-6 February 1997. International Union for the Scientific Study of Population: Durban.

GEBALLE, S. \& GRUENDEL, J. 1998. Forgotten children of the AIDS epidemic. London: Yale University Press.

GERMAN, S. 2004. Psychosocial impact of HIV/AIDS on children. Medical Research Council Aids Bulletin, 13(2):18-22.

GIESE, S., MEINTJES, H., CROKE, R. \& CHAMBERLAIN, R. 2003. Health and social services to address the needs of orphans and other vulnerable children in the context of HIV/AIDS in South Africa: Research report and recommendations. Report directed to Department of Health, January 2003. Cape Town: Children's Institute, University of Cape Town. GRIESEL-ROUX, E. 2004. A case study exploring learners' experiences of HIV/AIDS programmes. Pretoria: University of Pretoria. (D. Phil (Psych) dissertation)

GUBA, E.G. \& LINCOLN, Y.S. 1989. Fourth generation evaluation. Beverley Hills: Sage.

HUNTER, S. \& WILliAMSON, J. 2002. Children on the Brink. Strategies to support Children Isolated by HIV/AIDS. Arlington USA: US Agency for International Development (USAID).

LIGHT, M. 2004. Adolescence: Change and continuity: Cognitive transitions. Available: http://inside.bard.edu/academic/specialproj/darling/adpeer1.htm. [Rev. 2004/08/06].

LOUW, D.A., VAN EDE, D.M. \& LOUW, A.E. 1998. Menslike ontwikkeling ( $3^{\mathrm{e}}$ uitg). Kaapstad: Kagiso Tersiêr.

MABUTHO, S. 2004. The experience of elderly grandmother caregivers and AIDS orphans. Port Elizabeth: University of Port Elizabeth. (MA (SW) dissertation) 
MEINTJES, H., BUDLENDER, D., GIESE, S. \& JOHNSON, L. 2005. Children 'in need of care' or in 'need of cash'? Social security in the time of aids. South African Review of Sociology, $36(2): 238-268$.

MEINTJES, H., MOSES, S., BERRY, L. \& MAMPANE, R. 2007. Home truths: The phenomenon of residential care for children in a time of aids. Children's Institute, Centre for the study of AIDS. Pretoria: University of Pretoria.

NELSON MANDELA CHILDREN'S FUND. 2001. Report on: A study into the situation and special needs of children in child headed households. Pretoria: Nelson Mandela Children's Fund.

NEUMAN, W.L. 2000. Social research methods: Qualitative and quantitative approaches $\left(4^{\text {th }}\right.$ ed). Boston: Allyn \& Bacon.

POGGENPOEL, M. 1998. Data analysis in qualitative research. In: DE VOS, A.S. (ed) Research at grassroots: A primer for the caring professions. Pretoria: JL van Schaik Academic.

RICHTER, L., MANEGOLD, J. \& PATHER, R. 2004. Family and community interventions for children affected by AIDS. Cape Town: HSRC Publishers.

SMART, R., PLEANER, P. \& DENNIL, S. 2000. A primary HIV/AIDS capacity development course for government planners. Pretoria: Department of Social Development.

STRODE, A. \& GRANT, K. 2001. The role of stigma and discrimination in the vulnerability of children and youth infected with and affected by HIV/AIDS. Report commissioned by Save the Children (UK). Pretoria: Save the Children.

TUTTY, L.M., ROTTHERY, M. \& GRINNELL, R.M. 1996. Qualitative research for social workers. Needham Heights: Allyn \& Bacon.

UNICEF. 2003. Africa's orphaned generation. New York: UNICEF.

USAID. 2002. Children on the brink. Strategies to support children isolated by HIV/AIDS. Washington DC: USAID.

VIVIERS, A. 2004. The application of the developmental approach with respect to assessment and programmes for children and youth. Pretoria: UNESCO.

Ms Lynette Louw, MA social work studen, Dr Kotie Joubert, Senior Lecturer, Department of Social Work and Criminology, University of Pretoria, Pretoria, South Africa. 